\title{
A Literature Review on "Brand" in between 2010-2015
}

\author{
Bahtışen Kavak, Şerife Kazancı, Elif Tuğba Şahin, and Niray Tunçel
}

\begin{abstract}
The purpose of this study is to review the brand literature between 2010-2015 including three journals which have the name of 'brand' in their title. Within this purpose, three international academic journals were scanned. Through a comprehensive content analysis the literature divided into the main subjects as: 1. Brand Concepts, 2. Brand Management, 3. Brand Equity, 4. Brand Attitude. Besides, it is found out that widely studied subjects are brand strategy and branding. Most of the papers used quantitative methods and collected data from consumers via convenience sampling. The most important limitation is that this study concerns only three journals. It is believed that his pioneering study can motivate academicians to lead the topic of brand.
\end{abstract}

Index Terms-Brand, literature review, content analysis.

\section{INTRODUCTION}

Brand is a firm asset that contributes identity and character, guides consumers for product choices and forms the relations among consumers. Brand has several benefits for firms, consumers and society. In terms of consumers, brand is a quality indicator and creates awareness for products [1]. In terms of firms, brand provides customer loyalty, consistent sales amount and a high profit margin [2], [3]. As a result of consumer and firm benefits, brand plays a key role on social development. In intense competence conditions, firms need to create strong brands in order to survive and gain a competitive advantage.

Due to the importance of brand for consumers, firms and society, it has been a popular subject, which is focused by both researchers and practitioners. In this context, this study aims to conduct a literature review on brand in between 2010-2015.

Literature review is one of the most efficient ways of gathering the previous opinions and ideas related to the past studies. Okoli and Schabram [4] identify three types of literature reviews: 1) Literature reviews as theoretical foundation for primary research; 2) Literature reviews for graduate student theses; and 3) Stand-alone literature review. When literature review gives a theoretical foundation for a primary research, it presents the significance of the previous works and covers the content and quality of the existing knowledge. Besides this, literature review for graduate student thesis comes as a synthesis of the student's knowledge on the subject he focuses on, a proof of student's research dedication, a justification for future studies and a path that brings student

Manuscript received September 4, 2015; revised December 21, 2015.

The authors are with the Business Administration Department of Hacettepe University, Ankara, Turkey (e-mail: bahtisenkavak@gmail.com, srfekazanci@gmail.com, niraytuncel@hacettepe.edu.tr). into the academic tradition and etiquette [5]. As the last category of literature review is stand-alone literature review is a full-length paper the main purpose of which just to review the literature on a particular area without a primary data. When it is conducted in a systematic way, it becomes systematic literature review, which is defined by Fink [6] as a systematic process that is following a methodological approach, explicitly explaining conducted procedures, comprehensively covers the all related instruments and can be reproduced by other researchers adopting the same approach to the reviewed area.

In present study, from the approaches all above, systematic literature review is chosen. In parallel with the aim of the present research that is to classify the literature on brand in between 2010-2015 categorically, the literature review is subjected to a content analysis.

\section{RESEARCH METHODOLOGY}

Content analysis technique is defined as a systematic, repeated technique for compressing many words of text into fewer content categories based on explicit rules of coding [7], [8]. Content analysis helps researches to sieve the large amount of data with easing in a systematic process [9].

In this paper, three journals "Journal of Product \& Brand Management (JPBM)", "IUP Journal of Brand Management (IUP JBM)" and "Journal of Brand Management (JBM)" were investigated. Those journals are the ones that include "brand" in their title names, and published in between 20102015. The distribution of brand-related articles by the name of journals is presented in Table I.

TABLE I: DISTRIBUTION OF THE ARTICLES BY JOURNALS

\begin{tabular}{ccc}
\hline \hline Name of Journal & Number of $\operatorname{Articles}(\boldsymbol{n})$ & $\begin{array}{c}\text { Percentage of Articles } \\
(\boldsymbol{\%})\end{array}$ \\
\hline JPBM & 143 & 34,96 \\
IUP JPM & 60 & 14,67 \\
JBM & 206 & 50,37 \\
TOTAL & $\mathbf{4 0 9}^{*}$ & 100,00 \\
* Reference list of the articles can be obtained from the researchers. \\
\hline \hline
\end{tabular}

Moreover, systematic categorical classification of investigated articles is conducted by subject, year, type of study, research design, data collection method, analysis method, main population, sampling method, sampling size and country.

\section{ANALYSIS AND FINDINGS}

Based on 409 articles, the main topics are classified with their keywords as follows and presented in Table II.

1) Brand Concepts: Brand Image, Brand Identity, Brand Personality, Brand Awareness, Brand Loyalty, Brand Value, Brand Vulnerability, Brand Engagement, Brand Evangelism, Brand Commitment, Brand Trust, Brand 
Recognition, Brand Heritage, Brand Conscience.

2) Brand Management: Branding (corporate, employer, place and others), Brand Strategy, Brand Communication.

3) Brand Equity

4) Brand Attitude

TABLE II: DISTRIBUTION OF THE ARTICLES BY SUBJECTS

\begin{tabular}{|c|c|c|c|c|c|}
\hline \multirow{2}{*}{ SUBJECTS } & \multirow{2}{*}{$\begin{array}{l}\text { JPB } \\
\text { M }\end{array}$} & \multirow{2}{*}{$\begin{array}{l}\text { IUP } \\
\text { JBM }\end{array}$} & \multirow{2}{*}{ JBM } & \multicolumn{2}{|c|}{ " OVERALL TOTAL } \\
\hline & & & & $n$ & $(\%)$ \\
\hline $\begin{array}{l}\text { BRAND } \\
\text { CONCEPTS }\end{array}$ & 31 & 11 & 37 & 79 & 19,32 \\
\hline Brand Image & 9 & 2 & 4 & 15 & 3,67 \\
\hline Brand Identity & 2 & 1 & 4 & 7 & 1,71 \\
\hline Brand Personality & 3 & 3 & 8 & 14 & 3,42 \\
\hline Brand Awareness & 0 & 0 & 1 & 1 & 0,24 \\
\hline Brand Loyalty & 7 & 1 & 5 & 13 & 3,18 \\
\hline Brand Value & 1 & 1 & 3 & 5 & 1,22 \\
\hline $\begin{array}{l}\text { Brand } \\
\text { Vulnerability }\end{array}$ & 0 & 0 & 1 & 1 & 0,24 \\
\hline $\begin{array}{l}\text { Brand } \\
\text { Engagement }\end{array}$ & 3 & 0 & 1 & 4 & 0,98 \\
\hline Brand Evangelism & 1 & 0 & 0 & 1 & 0,24 \\
\hline $\begin{array}{l}\text { Brand } \\
\text { Commitment }\end{array}$ & 3 & 1 & 0 & 4 & 0,98 \\
\hline Brand Trust & 1 & 1 & 0 & 2 & 0,49 \\
\hline Brand Recognition & 0 & 1 & 0 & 1 & 0,24 \\
\hline Brand Heritage & 1 & 0 & 1 & 2 & 0,49 \\
\hline Brand Conscience & 0 & 0 & 2 & 2 & 0,49 \\
\hline Brand Reputation & 0 & 0 & 1 & 1 & 0,24 \\
\hline Brand Strength & 0 & 0 & 1 & 1 & 0,24 \\
\hline $\begin{array}{l}\text { Brand } \\
\text { Empowerment }\end{array}$ & 0 & 0 & 1 & 1 & 0,24 \\
\hline $\begin{array}{l}\text { Brand } \\
\text { Anthropomorphism }\end{array}$ & 0 & 0 & 1 & 1 & 0,24 \\
\hline $\begin{array}{l}\text { Brand Leadership } \\
\text { BRAND }\end{array}$ & 0 & 0 & 1 & 1 & 0,24 \\
\hline MANAGEMENT & & & & & \\
\hline Branding & 20 & 11 & 54 & 85 & 20,78 \\
\hline $\begin{array}{l}\text { Corporate } \\
\text { Branding }\end{array}$ & 7 & 1 & 14 & 22 & 5,38 \\
\hline Employer Branding & 1 & 5 & 3 & 9 & 2,20 \\
\hline Place Branding & 2 & 0 & 7 & 9 & 2,20 \\
\hline Other & 10 & 5 & 30 & 45 & 11,00 \\
\hline Brand Strategy & 40 & 20 & 53 & 113 & 27,63 \\
\hline $\begin{array}{l}\text { Brand } \\
\text { Communication }\end{array}$ & 8 & 4 & 15 & 27 & 6,60 \\
\hline BRAND EQUITY & 16 & 8 & 14 & 38 & 9,29 \\
\hline $\begin{array}{l}\text { BRAND } \\
\text { ATTITUDE }\end{array}$ & 28 & 6 & 33 & 67 & 16,38 \\
\hline TOTAL & 143 & 60 & 206 & 409 & 100,00 \\
\hline
\end{tabular}

Note: Classification is parallel to the contents of the text book of Kapferer (2008) [1].

According to Table II, of the 409 papers, 113 goes to brand strategy, 85 goes to branding, 79 goes to brand concepts and 67 goes to brand attitude, 38 goes to brand equity and 27 goes to brand communication.

"Brand Strategies" and "Branding" are the topics mostly investigated. So it could be stated that "Brand Management" issue comes first in literature.

The other point might be highlighted on the table is that Journal of Product and Brand Management has the widest range of topics. For example, brand evangelism and brand engagements are for only in this journal. However, Journal of Brand Management has the highest number of papers directly related to the brand issue. Subjects mostly focus on the branding and branding strategy.

Table III provides the subject distribution by years. According to Table III, it can be stated that the average number of studies by year is more or less is between 70 and 80.
TABLE III: DISTRIBUTION OF SUBJECTS STUDIED IN ARTICLES BY YEARS

\begin{tabular}{|c|c|c|c|c|c|c|c|c|}
\hline \multirow{2}{*}{ SUBJECTS } & \multicolumn{2}{|c|}{2010} & \multicolumn{2}{|c|}{2011} & \multicolumn{2}{|c|}{2012} & & \\
\hline & $n$ & $\%$ & $n$ & $\%$ & $n$ & $\%$ & & \\
\hline Brand Concepts & 13 & 16,67 & 16 & 21,92 & 14 & 17,50 & & \\
\hline Branding & 13 & 16,67 & 15 & 20,55 & 16 & 20,00 & & \\
\hline Brand Strategy & 32 & 41,03 & 18 & 24,66 & 20 & 25,00 & & \\
\hline $\begin{array}{l}\text { Brand } \\
\text { Communication }\end{array}$ & 3 & 3,85 & 6 & 8,22 & 5 & 6,25 & & \\
\hline Brand Equity & 7 & 8,97 & 7 & 9,59 & 10 & 12,50 & & \\
\hline Brand Attitude & 10 & 12,82 & 11 & 15,07 & 15 & 18,75 & & \\
\hline TOTAL & 78 & & 73 & & 80 & & & \\
\hline \multirow{2}{*}{ SUBJECTS } & \multicolumn{2}{|c|}{2013} & \multicolumn{2}{|c|}{2014} & \multicolumn{2}{|c|}{2015} & \multicolumn{2}{|c|}{ TOTAL* } \\
\hline & $n$ & $\%$ & $n$ & $\%$ & $n$ & $\%$ & $n$ & $\%$ \\
\hline Brand Concepts & 14 & 18,67 & 13 & 18,57 & 9 & 27,27 & 79 & 19,32 \\
\hline Branding & 25 & 33,33 & 12 & 17,14 & 6 & 18,18 & 87 & 21,27 \\
\hline Brand Strategy & 18 & 24,00 & 15 & 21,43 & 10 & 30,30 & 113 & 27,63 \\
\hline $\begin{array}{l}\text { Brand } \\
\text { Communication }\end{array}$ & 6 & 8,00 & 5 & 7,14 & 2 & 6,06 & 27 & 6,60 \\
\hline Brand Equity & 3 & 4,00 & 9 & 12,86 & 2 & 6,06 & 38 & 9,29 \\
\hline Brand Attitude & $\begin{array}{l}9 \\
\mathbf{7 5}\end{array}$ & 12,00 & $\begin{array}{l}16 \\
70\end{array}$ & 22,86 & $\begin{array}{l}4 \\
33\end{array}$ & 12,12 & $\begin{array}{l}65 \\
409\end{array}$ & 15,89 \\
\hline
\end{tabular}

Table III also says that brand strategy is the top topic of the years 2010, 2011, 2012 and 2015; branding is the top topic of 2013; brand attitude is the top topic of 2014.

Table IV provides the number of empirical and conceptual papers for each journal.

\begin{tabular}{llllrc}
\multicolumn{2}{c}{ TABLE IV: DISTRIBUTION OF ARTICLES BY TYPE OF STUDY } \\
\hline \hline $\begin{array}{l}\text { TYPE } \\
\text { STUDY }\end{array}$ & \multirow{2}{*}{ JPBM } & IUP JBM & JBM & \multicolumn{2}{c}{ TOTAL } \\
\hline Empirical & 133 & 42 & 169 & 344 & 84,11 \\
Conceptual & 10 & 18 & 37 & 65 & 15,89 \\
TOTAL & $\mathbf{1 4 3}$ & $\mathbf{6 0}$ & $\mathbf{2 0 6}$ & $\mathbf{4 0 9}$ & 100,00 \\
\hline \hline
\end{tabular}

\begin{tabular}{|c|c|c|c|c|c|c|c|c|}
\hline \multirow{2}{*}{$\begin{array}{l}\text { RESEARCH } \\
\text { DESIGN } \\
\text { Qualitative }\end{array}$} & \multicolumn{2}{|c|}{ JPBM } & \multicolumn{2}{|c|}{ IUP JBM } & \multicolumn{2}{|c|}{ JBM } & \multicolumn{2}{|c|}{ TOTAL } \\
\hline & 34 & 25,56 & 12 & 28,57 & 50 & 29,58 & 96 & 27,90 \\
\hline Quantitative & 82 & 61,65 & 24 & 57,14 & 108 & 63,90 & 214 & 62,20 \\
\hline $\begin{array}{l}\text { Qualitative+ } \\
\text { Quantitative }\end{array}$ & 17 & 12,78 & 6 & 14,28 & 11 & 6,50 & 34 & 9,88 \\
\hline TOTAL & 133 & 100,00 & 42 & 100,00 & 169 & 100,00 & 344 & 100,00 \\
\hline
\end{tabular}

TABLE VI: DiSTRIBUTION OF EMPIRICAL ARTICLES BY DATA COLLECTION METHOD

\begin{tabular}{llllll}
\hline $\begin{array}{l}\text { Data Collection } \\
\text { Method }\end{array}$ & JPBM & IUP JBM & JBM & $\begin{array}{r}\text { TOTAL } \\
(\%)\end{array}$ \\
\hline Survey method & 94 & 29 & 110 & $\mathbf{2 3 3}$ & $\mathbf{6 2 , 3 0}$ \\
In-depth interviews & 21 & 5 & 17 & 43 & 11,50 \\
Case study & 12 & 8 & 22 & 42 & 11,23 \\
Focus Group & 4 & 2 & 5 & 11 & 2,94 \\
Observation & 0 & 0 & 1 & 1 & 0,27 \\
Document review* & 1 & 4 & 7 & 12 & 3,21 \\
Content analysis** & 7 & 3 & 7 & 17 & 4,55 \\
Panel data & 3 & 0 & 1 & 4 & 1,07 \\
Secondary data *** & 5 & 0 & 6 & 11 & 2,94 \\
TOTAL & $\mathbf{1 4 7}$ & $\mathbf{5 1}$ & $\mathbf{1 7 6}$ & $\mathbf{3 7 4}$ & 100,00 \\
\hline *Articles **Web site, Brand, Icon, Slogan, Advertising ***Database
\end{tabular}

*Articles **Web site, Brand, Icon, Slogan, Advertising ***Database

As seen in Table IV, 84.11 percent (344) of the articles is empirical and 15.89 percent (65) is conceptual. Thus, it might be stated that empirical studies have special emphasis for the researchers.

When it comes to the classification according to the research design, Table $\mathrm{V}$ shows that in 344 empirical studies, the share of quantitative research is 63.90 percent and the share of qualitative research is 29.58 percent. In 6.5 percent of the studies, both qualitative and quantitative methods were used together. It can be concluded that most 
of the researches were conducted quantitatively.

In those quantitative researches, the data collected through survey method $(233, \% 62.30)$ while qualitative researches generally uses in-depth interviews (43, \%11.5) and case studies (42,\%11.23), as it is seen in Table VI.

The empirical research papers were also analyzed in terms of their analysis method and findings are presented in Table VII.

TABLE VII: DISTRIBUTION OF THE ARTICLES BY ANALYSIS METHOD

\begin{tabular}{|c|c|c|c|c|c|}
\hline $\begin{array}{l}\text { ANALYSIS TECHNIQUE } \\
\text { Quantitative Methods }\end{array}$ & JPBM & $\begin{array}{l}\text { IUP } \\
\text { JBM }\end{array}$ & JBM & $\begin{array}{r}\text { TOT } \\
n \\
376 \\
\end{array}$ & $\begin{array}{r}(\%) \\
83,37 \\
\end{array}$ \\
\hline SEM & 26 & 6 & 26 & 58 & 12,86 \\
\hline Manova & 8 & 0 & 10 & 18 & 3,99 \\
\hline Anova & 13 & 3 & 27 & 43 & 9,53 \\
\hline Factor Analysis & 26 & 6 & 35 & 67 & 14,86 \\
\hline Regression & 26 & 8 & 28 & 62 & 13,75 \\
\hline Mancova & 3 & 0 & 1 & 4 & 0,89 \\
\hline Ancova & 2 & 0 & 2 & 4 & 0,89 \\
\hline Cluster & 2 & 1 & 6 & 9 & 2 \\
\hline Correlation & 9 & 0 & 12 & 21 & 4,66 \\
\hline Chi-square & 5 & 1 & 3 & 9 & 2 \\
\hline T-Test & 7 & 0 & 10 & 17 & 3,77 \\
\hline Frequency & 2 & 2 & 1 & 5 & 1,11 \\
\hline Pls/Path Analysis & 3 & 0 & 13 & 16 & 3,55 \\
\hline Principal Component Analysis & 1 & 0 & 4 & 5 & 1,11 \\
\hline Variance & 1 & 0 & 6 & 7 & 1,55 \\
\hline Descriptive Statistics & 6 & 1 & 2 & 9 & 2 \\
\hline Other* & 7 & 6 & 9 & 22 & 4,88 \\
\hline Qualitative Methods & & & & 75 & 16,62 \\
\hline Content Analysis & 19 & 5 & 35 & 59 & 13,08 \\
\hline Semiotic & 2 & 11 & 0 & 13 & 2,88 \\
\hline Meta Analysis & 0 & 1 & 2 & 3 & 0,67 \\
\hline TOTAL & & & & 451 & 100 \\
\hline
\end{tabular}

*Econometric analysis (3), F test (1), Cross Tabulation (4), Mediation and Moderation test (2), Z Test (3),Friedman (1), Percentage Analysis (1), Sobel test (1), Kruskal-Wallis(4), Man Whitney(1), Post Hoc (1), MFIRT Anaysis (1), Robustness test (1), Sensitivity Analysis (1), Discriminat Analysis (1)

As seen in Table VII, 83.37 percent (376) of the articles uses quantitative methods and 16.62 percent (75) uses qualitative methods. Of the quantitative methods, most frequently used one is factor analysis with 1.86 percent (67) and of the qualitative methods most frequently used one is content analysis with 13.08 percent (59).

Another frame the articles are examined is main population results of which is presented in Table VIII.

\begin{tabular}{llllll}
\multicolumn{5}{c}{ TABLE VIII: DISTRIBUTION OF THE ARTICLES BY MAIN POPULATION } \\
\hline \hline $\begin{array}{l}\text { MAIN } \\
\text { POPULATION }\end{array}$ & JPBM & IUP JBM & JBM & & TOTAL \\
& & & & $\boldsymbol{n}$ & $(\boldsymbol{\%})$ \\
\hline Student & 43 & 10 & 47 & $\mathbf{1 0 0}$ & 29,24 \\
Consumer & 59 & 13 & 53 & $\mathbf{1 2 5}$ & 36,55 \\
Worker & 3 & 5 & 6 & $\mathbf{1 4}$ & 4,09 \\
Manager & 9 & 2 & 12 & $\mathbf{2 3}$ & 6,73 \\
Firm & 4 & 0 & 8 & $\mathbf{1 2}$ & 3,51 \\
Expert & 2 & 1 & 3 & $\mathbf{6}$ & 1,75 \\
Association Member & 4 & 0 & 3 & $\mathbf{7}$ & 2,05 \\
Studies in Literature & 1 & 1 & 5 & $\mathbf{7}$ & 2,05 \\
Non-Person* & 9 & 3 & 13 & $\mathbf{2 5}$ & 7,31 \\
User** & 5 & 0 & 8 & $\mathbf{1 3}$ & 3,80 \\
Other*** & 7 & 1 & 2 & $\mathbf{1 0}$ & 2,92 \\
TOTAL & $\mathbf{1 4 6}$ & $\mathbf{3 6}$ & $\mathbf{1 6 0}$ & $\mathbf{3 4 2}$ & 100,00 \\
\hline
\end{tabular}

*Newspaper, Brand Communities, Secondary Data, Blog, Brand, Publicity, Messages, Slogan, Icon ** Social Media Users *** Voter, external stakeholder, physician, retailer, designer, resident

In 36.55 percent (125) of the studies, the main population consists of consumers and students come second with 29.24 percent (100). The reason for this might be that consumers and students are more accessible.

The empirical research papers were also analyzed in terms of their sampling methods shown in Table IX. Surprisingly, there is no information about sampling method in many of the papers. Due to this reason, researchers have chosen an interpretative approach to determine the sampling methods in those studies.

\begin{tabular}{|c|c|c|c|c|c|}
\hline \multirow{2}{*}{$\begin{array}{l}\text { SAMPLING } \\
\text { METHOD }\end{array}$} & \multirow{2}{*}{ JPBM } & \multirow{2}{*}{ IUP JBM } & \multirow{2}{*}{ JBM } & \multicolumn{2}{|c|}{ TOTAL } \\
\hline & & & & $n$ & $(\%)$ \\
\hline \multicolumn{4}{|c|}{ Probability Sampling } & 55 & 15,9 \\
\hline $\begin{array}{l}\text { Simple } \\
\text { Random }\end{array}$ & 23 & 9 & 16 & 48 & 13,95 \\
\hline Systematic & 3 & 0 & 1 & 4 & 1,16 \\
\hline Stratified & 1 & 0 & 0 & 1 & 0,29 \\
\hline Cluster & 2 & 0 & 0 & 2 & 0,58 \\
\hline \multicolumn{4}{|c|}{ Unprobability Sampling } & 289 & 84,01 \\
\hline$\overline{\text { Convenience }}$ & 99 & 29 & 137 & 265 & 77,03 \\
\hline Snowball & 2 & 0 & 4 & 6 & 1,74 \\
\hline Quota & 3 & 1 & 4 & 8 & 2,33 \\
\hline Judgment & 0 & 3 & 7 & 10 & 2,91 \\
\hline TOTAL & 133 & 42 & 169 & 344 & 100,00 \\
\hline
\end{tabular}

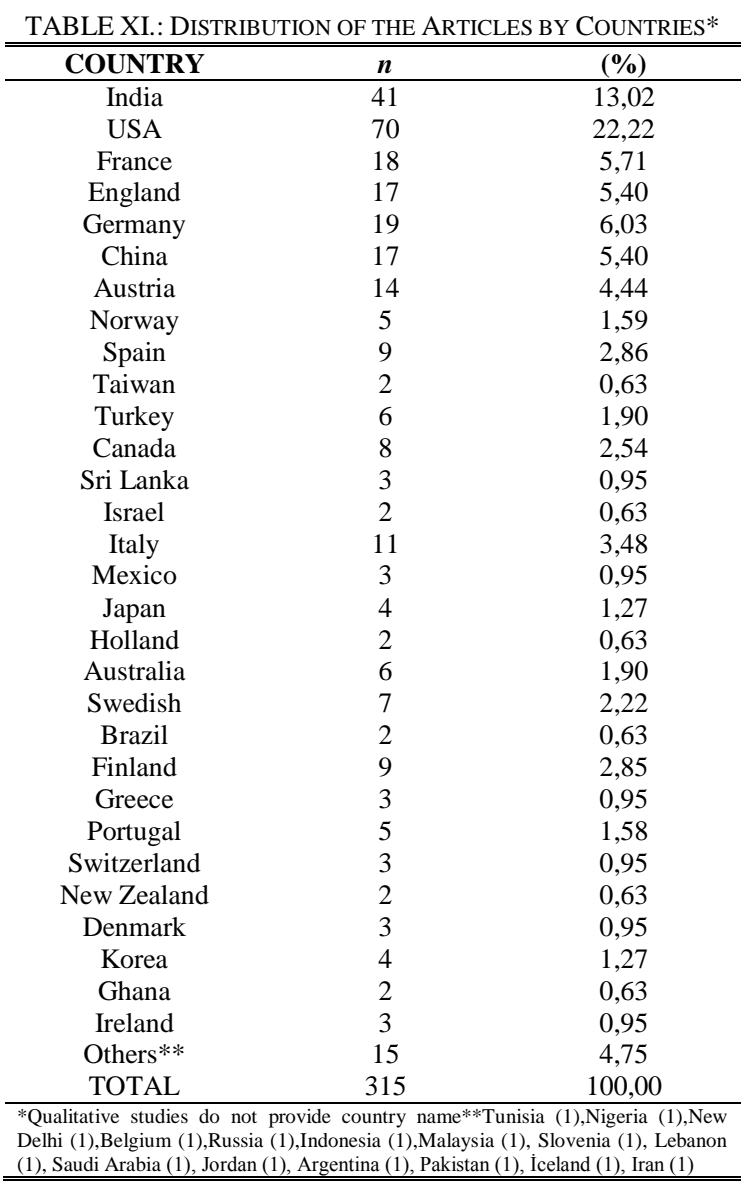

As seen in Table IX, 15.99 percent (55) of the articles uses probability sampling and 84.01 percent (289) uses nonprobability sampling. Of the probability samplings, the most frequently used one is simple random method with 13.95 percent (48) and of the unprobability samplings, the most frequently used one is the convenience one with 77.03 percent (265). Other methods are used rarely. It might be inferred that researchers consider cost and time limitations so they usually prefer to use nonprobability sampling methods.

Moreover, the papers were categorized in terms of 
sample size for both qualitative and quantitative researches as seen from Table $\mathrm{X}$.

TABLE X: DiSTRIBUTION OF THE ARTICLES BY SAMPLE SIZES

\begin{tabular}{llllll}
\hline $\begin{array}{c}\text { Quantitative } \\
\text { Design } \\
\text { Sample Size }\end{array}$ & $\boldsymbol{n}$ & \multicolumn{5}{c}{$\boldsymbol{( \% )}$} & \multicolumn{1}{c}{$\begin{array}{c}\text { Qualitative } \\
\text { Sesign }\end{array}$} \\
\hline $1-100$ & 19 & 7,34 & $1-10$ & 10 & 14,49 \\
$101-200$ & 58 & 22,39 & $11-20$ & 26 & 37,68 \\
$201-300$ & 50 & 19,31 & $21-30$ & 11 & 15,94 \\
$301-400$ & 35 & 13,51 & $31-40$ & 3 & 4,35 \\
$401-500$ & 18 & 6,95 & $41-50$ & 1 & 1,45 \\
$501-600$ & 13 & 5,02 & $51-70$ & 4 & 5,80 \\
$601-700$ & 18 & 6,95 & $71-100$ & 3 & $4,35 \%$ \\
$701-800$ & 12 & 4,63 & $101-200$ & 4 & 5,80 \\
$801-900$ & 6 & 2,32 & $201-300$ & 4 & 5,80 \\
$901-1000$ & 8 & 3,09 & $301-400$ & 0 & 0,00 \\
$1000<$ & 22 & 8,49 & $400<$ & 3 & 4,35 \\
TOTAL & $\mathbf{2 5 9}$ & 100,00 & TOTAL & $\mathbf{6 9}$ & 100,00 \\
\hline *Only the papers that give information about sample size are included.
\end{tabular}

It is observed that, in quantitative studies, sample size accumulates between 101 and $200(n=58, \%$ 22.39) while in qualitative studies, sample size accumulates between 11 and $20(n=26, \% 37.68)$.

Finally, the papers were also analyzed in terms of country in which the study is conducted. Table XI includes only the distribution of the countries for only empirical studies.

According to Table XI USA is the first country where most of the brand related studies are conducted (70, \%22.22) and India is the second one (41, \%13.02). Additionally, the studies are coming from 46 different countries.

\section{CONCLUSION AND RESEARCH IMPLICATIONS}

This paper presents a comprehensive review and a system of classification for 409 brand related articles that were published between 2010 and 2015 in three international academic journals. The paper is a helpful summary of the literature, and will be useful for further researches.

Systematic categorical classification of literature is conducted by subject, year, type of study, research design, data collection method, analysis method, main population, sampling method, sampling size and country.

Studies were classified under four main subjects as Brand Concepts, Brand Management, Brand Equity and Brand Attitude. From all these subjects, Brand Management and Brand Concepts are the most studied ones. However, it is seen that there are many sub-subjects under the Brand Concepts, which did not take attention of researchers properly. For instance, some recent concepts such as brand evangelism, brand recognition, brand heritage, brand reputation are very rarely studied, which provides a big opportunity for further researches.

Another interesting issue is that the number of conceptual studies is five times less than the number of empirical studies. Hence, in terms of three journals it is needed to establish some preliminary insights for new theoretical topics.

When it comes to research design, quantitative approach maintains its dominating position. Thus, it might be inferred that there is still a need for more qualitative and mixed research designs in brand-related studies.

Another point is that in considerable amount of studies, there is no information about main population, sampling method, sample size and type of analysis. However, to clarify all these issues in scientific papers is crucial since methodological information can increase the reliability of the studies.

Eventually, it is also revealed that brand studies pile up in two countries: USA and India. Studies conducted in these two countries generate the one-third of all studies conducted in 45 countries. Therefore, it can be suggested that to bring as many as discrete perspectives into the brand literature, increasing number of studies should come from different countries.

\section{LIMITATIONS OF THE STUDY AND IMPLICATIONS FOR FURTHER RESEARCHES}

The most important limitation is that this study concerns only three journals. It might be expanded to a brand literature by including some well-known journals for example Journal of Marketing, Journal of Marketing Research, and European Journal of Marketing etc.

\section{CONTRIBUtion OF THE StUdy}

The present study provides a very considerable attention to the last six years brand literature so this pioneering study can motivate academicians to lead the topic of brand.

\section{REFERENCES}

[1] J. Kapferer, The New Strategic Brand Management: Creating and Sustaining Brand Equity Long Term, 4th ed., London, 2008.

[2] P. Kotler and W. Pfoertsch, B2B Brand Management, Berlin: Springer, 2006

[3] K. L. Keller, Building Customer-Based Brand Equity: A Blueprint for Creating Strong Brands, Marketing Science Institute, 2001

[4] C. Okoli and K. Schabram, "A guide to conducting a systematic literature review of information systems research," 2010.

[5] C. Bruce, "Interpreting the scope of their literature reviews: Significant differences in research students' concerns," New Library World, vol. 102, no. 4/5, pp. 158-166, 2001.

[6] A. Fink, Conducting Research Literature Reviews: From the Internet to Paper, 2nd ed. California: Sage Publications, 2005.

[7] K. Krippendorff, Content Analysis: An Introduction to its Methodology, London: Sage, 1980.

[8] R. P. Weber, Basic Content Analysis, 2nd ed. Sage, Newbury Park, CA, 1990.

[9] U.S. General Accounting Office, Content Analysis: A Methodology for Structuring and Analyzing Written Material, GAO/PEMD-10.3.1. Washington, D.C., 1996.

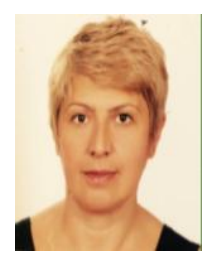

Bahtışen Kavak was born in Artvin, Turkey. She has received $\mathrm{MS}$ and $\mathrm{PhD}$ degrees in business administration from Hacettepe University, Ankara, Turkey. She has been interested in marketing research, industrial marketing, international marketing and marketing models.

She is working as a professor of marketing at Hacettepe University in Ankara, Turkey.

Prof. Kavak is the president of Marketing and Marketing Research Association (PPAD).

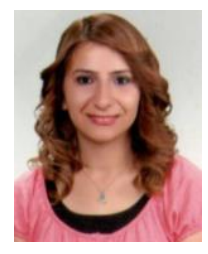

Şerife Kazancı was born in Karaman, Turkey. She received an MS degree in marketing from Hacettepe University in 2014. She has started her $\mathrm{PhD}$ at Hacettepe University, Institute of Social Sciences, Department of Business Administration. Her areas of interest include marketing research, brand management and 
social media activities.

She is also working as a research assistant in the Business Administration Department at Hacettepe University, Ankara, Turkey.

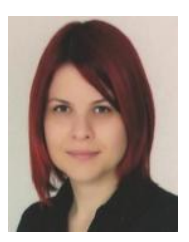

Elif Tuğba Şahin was born in Kayseri, Turkey. She completed her master education with the thesis in the marketing field. She still continues her $\mathrm{PhD}$ education at the Department of Business Administration at Institute of Social Sciences, Hacettepe University, Ankara, Turkey. Her brand management
She is working as a research assistant at the Faculty of Business Administration at University of Turkish Aeronautical Association.

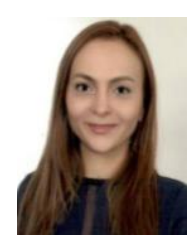

Niray Tunçel was born in Ankara, Turkey. She has received her master degree of marketing in 2011 at Bahçeşehir University in Istanbul. She is doing her $\mathrm{PhD}$ at Hacettepe University in Ankara. She has an interest in the field of marketing research, industrial marketing and consumer ethics.

She works as a research assistant at Hacettepe University in Ankara, Turkey. 